\title{
TINJAUAN YURIDIS TERHADAP HUBUNGAN SERTIFIKASI HALAL PADA SUATU PRODUK DENGAN PERLINDUNGAN HUKUM BAGI KONSUMEN
}

\author{
Oleh \\ Jatmiko Winarno \\ Dosen Fakultas Hukum Universitas Islam Lamongan
}

\begin{abstract}
Abstrak
Indonesia yang mayoritas penduduknya beragama Islam sudah seharusnya mendapat perlindungan hukum terhadap kehalalan makanan untuk dikonsumsi karena mengkonsumsi produk halal adalah suatu kewajiban dan makanan yang halal itu sudah pasti sehat. Hal ini sangat erat kaitannya dengan sertifikasi halal. Menurut Pasal 1 angka 10 Undang-Undang Nomor 33 Tahun 2014 Tentang Jaminan Produk Halal, sertifikat halal adalah pengakuan kehalalan suatu produk yang dikeluarkan oleh Badan Penyelenggara Jaminan Produk Halal (BPJPH) berdasarkan fatwa tertulis yang dikeluarkan oleh Majelis Ulama Indonesia. Secara mendasar Peneliti dalam Penelitian ini menggunakan pendekatan undang-undang (statuteapproach) dengan menelaahUndang-undang Nomor 33 Tahun 2014 tentang Jaminan Produk Halal, Undang- Undang Nomor 7 Tahun 1996 tentang Pangan (selanjutnya disebut Undang-undang Pangan), Undang-undang Nomor 8 Tahun 1999 tentang Perlindungan Konsumen (selanjutnya disebut Undang- undang Perlindungan Konsumen) dan Peraturan Pemerintah Nomor 69 Tahun 1999 tentang Label dan Iklan Pangan.
\end{abstract}

Kata Kunci : Sertifikasi Halal, Perlindungan Hukum Konsumen

\section{PENDAHULUAN}

\section{Latar Belakang Masalah}

Dalam suatu kegiatan bisnis, banyak masalah yang kadang-kadang muncul begitu saja. Persaingan dalam kegiatan usaha senafas dengan kegiatan usaha itu sendiri. Pada prinsipnya, setiap orang berhak menjual atau membeli barang atau jasa "apa", "dengan siapa", "berapa banyak" serta "bagaimana cara" produksi, inilah apa yang disebut dengan ekonomi pasar. Sejalan dengan itu, perilaku dan struktur pasar terkadang tidak dapat diprediksi, sehingga tidak jarang menimbulkan kecurangan.

Pasar Indonesia merupakan pasar konsumen muslim yang sangat besar. Oleh karena itu, jaminan akan produk halal menjadi suatu yang penting untuk mendapatkan perhatian dari negara. Sebagaimana yang tercantum dalam Pembukaan Undang-Undang Dasar Negara Republik Indonesia Tahun 1945 bahwa
Negara berkewajiban melindungi segenap bangsa Indonesia dan seluruh tumpah darah Indonesia dan untuk mewujudkan kesejahteraan umum. Kehalalan suatu produk menjadi kebutuhan wajib bagi setiap konsumen, terutama konsumen muslim. Baik itu produk berupa makanan, obat-obatan maupun barang-barang konsumsi lainnya.

Perlindungan konsumen merupakan bagian tak terpisahkan dari kegiatan bisnis yang sehat. Pembangunan dan perkembangan perekonomian umumnya dan khususnya di bidang perindustrian dan perdagangan nasional telah menghasilkan berbagai variasi barang dan/atau jasa yang dapat dikonsumsi. Disamping itu, globalisasi dan perdagangan bebas yang didukung oleh kemajuan teknologi telah memperluas ruang gerak transaksi barang dan/atau jasa melintasi batas-batas wilayah suatu negara, sehingga barang dan/atau jasa yang ditawarkan mempunyai lebih 
banyak variasi baik produksi dalam maupun luar negeri.

\section{METODE PENELITIAN}

\section{Tipe Penelitian}

Metode Penelitian yang digunakan adalah yuridis Normatif Dalam penelitian pada umumnya dibedakan antara data yang diperoleh langsung dari masyarakat dan dari bahan pustaka. Diperoleh langsung dari masyarakat dinamakan data primer, sedangkan yang diperoleh dari bahanbahan pustaka lazimnya dinamakan data sekunder. Kemudian menginjak tentang pengertian penelitian hukum normatif itu sendiri yang menjadi metode penelitian yang digunakan oleh penulis, adapun definisi dari penelitian hukum normatif adalah penelitian hukum kepustakaan. Yang pada penelitian hukum normatif, bahan pustaka merupakan data dasar yang dalam ilmu penelitian digolongkan sebagai data sekunder.

\section{Pendekatan Masalah}

Jenis pendekatan yang digunakan penulis adalah pendekatan perundangundangan (statute approach). Pendekatan ini dilakukan dengan cara melihat segala undang-undang dan regulasi terkait isu hukum yang sedang diteliti. Dalam pendekatan ini peneliti dapat melihat konsistensi antara regulasi satu dengan regulasi yang lainnya. Metode pendekatan perundang-undangan peneliti dapat melihat dasar filosofi atau dasar pemikiran mengapa peraturan tersebut dikeluarkan.

\section{Bahan Hukum}

Adapun bahan hukum yang digunakan untuk menunjang metode penulisan yang digunakan adalah sebagai berikut:

a. Bahan Hukum Primer

Bahan hukum primer yaitu bahan hukum yang diperoleh dari hukum positif atau peraturan perundangundangan. Dalam penelitiaan hukum ini penulis menggunakan bahan hukum primer yaitu :

1. Undang-Undang Dasar 1945

2. Undang-undang Nomor 7 Tahun 1996 tentang Pangan
3. Undang-Undang Nomor 8 tahun 1999 tentang Perlindungan Konsumen

3. Undang-Undang Nomor 33 tahun 2014 tentang Jaminan Produk Halal

4. Peraturan Pemerintah Nomor 69 Tahun 1999 tentang Label dan Iklan Pangan

5. Keputusan Menteri Kesehatan RI No.924/Menkes/SK/VII/1996

Tentang Perubahan atas Keputusan Menteri Kesehatan No.82 Menkes/SK/I/1996 Tentang Pencantuman tulisan Halal Pada Label Makanan.

6. Keputusan Menteri Agama RI No.518 tahun 2001 tentang Pedoman dan Tata Cara Pemeriksaan dan Penetapan Pangan Halal.

7. Keputusan Menteri Agama RI No.519 Tahun 2001 tentang Lembaga Pelaksana Pemeriksa Pangan Halal.

b. Bahan Hukum Sekunder

Bahan Hukum Sekunder adalah bahan hukum yang memberikan penjelasan mengenai bahan hukum primer, yang terdiri dari buku, jurnal, makalah, dan lain-lain, sehingga dapat mendukung penelitian ini secara teoritis.

c. Bahan Hukum Tertier

Bahan hukum tertier adalah bahan hukum yang memberi petunjuk maupun penjelasan terhadap bahan hukum primer dan sekunder yang terdiri dari kamus, ensiklopedia dan hal lain yang bersangkutan dengan objek penelitian.

\section{Prosedur Pengumpulan Bahan Hukum}

Untuk mendapatkan dan mengumpulkan bahan hukum yang diperlukan didalam penulisan seperti yang telah disebutkan diatas, penulis menggunakan teknik studi kepustakaan (library Research). Teknik pengumpulan yang digunakan penulis ini adalah mempelajari dan melakukan analisis terhadap sumber-sumber atau bahan- 
bahan tertulis yang dijadikan bahan dalam penulisan skripsi ini.

\section{Pengolahan dan Analisis Bahan Hukum}

Dalam penulisan ini teknik analisa yang digunakan adalah deskriptif analisis yang berarti penulis dalam menganalisis berkeinginan untuk memberikan gambaran atau pemaparan atas subjek dan objek penelitian sebagaimana penelitian yang dilakukan dengan mencermati substansi perundang-undangan dan berbagai doktrin tersebut dalam mengkaji permasalahan terkait.

\section{HASIL PENELITIAN DAN PEMBAHASAN}

\section{Pengaturan Sertifikasi Produk Halal Di Indonesia Berdasarkan Undang- Undang Nomor 33 Tahun 2014 Tentang Jaminan Produk Halal}

Setiap produsen harus memenuhi kebutuhan dan hak konsumen, termasuk konsumen Muslim. Memproduksi produk halal adalah bagian dari tanggungjawab perusahaan kepada konsumen muslim. Di Indonesia, untuk memberikan keyakinan kepada konsumen bahwa produk yang dikonsumsi adalah halal, maka perusahaan perlu memiliki sertifikat halal. Oleh karena itu untuk melindungi konsumen muslim tersebut, dibentuklah suatu undang-undang untuk sebagai dasar legalitas atas produk halal yaitu UndangUndang Nomor 33 Tahun 2014 tentang Jaminan Produk Halal.

Secara mendasar Undang-Undang Nomor 33 Tahun 2014 tentang Jaminan Produk Halal, lahir dikarenakan adanya Undang- Undang Nomor 7 Tahun 1996 tentang Pangan (selanjutnya disebut Undang-undang Pangan), Undang-undang Nomor 8 Tahun 1999 tentang Perlindungan Konsumen (selanjutnya disebut Undang-undang Perlindungan Konsumen) dan Peraturan Pemerintah Nomor 69 Tahun 1999 tentang Label dan Iklan Pangan.
Undang-Undang Nomor 33 Tahun 2014 tentang Jaminan Produk Halal antara lain mengatur mengenai:

1. Untuk menjamin ketersediaan Produk Halal, ditetapkan bahan produk yang dinyatakan halal, baik bahan yang berasal dari bahan baku hewan, tumbuhan, mikroba, maupun bahan yang dihasilkan melalui proses kimiawai, proses biologi, atau proses rekayasa genetik. Di samping itu, Ditentukan pula PPH yang merupakan rangkaian kegiatan untuk menjamin kehalalan Produk yang mencakup penyediaan bahan, pengolahan, penyimpanan,pengemasan,

pendistribusian, penjualan, dan penyajian Produk.

2. Undang-Undang ini mengatur hak dan kewajiban Pelaku Usaha dengan memberikan pengecualian terhadap Pelaku Usaha yang memproduksi Produk dari Bahan yang berasal dari Bahan yang diharamkan dengan kewajiban mencantumkan secara tegas keterangan tidak halal pada kemasan Produk atau pada bagian tertentu dari Produk yang mudah dilihat, dibaca, tidak mudah terhapus, dan merupakan bagian yang tidak terpisahkan dari Produk.

3. Dalam rangka memberikan pelayanan publik, Pemerintah bertanggung jawab dalam menyelenggarakan JPH yang pelaksanaannya dilakukan oleh BPJPH.

Dalam menjalankan wewenangnya, BPJH bekerja sama dengan kementerian dan/atau lembaga terkait, MUI, dan LPH.

Di dalam Penjelasan Undang-Undang Nomor 33 Tahun 2014 tentang Jaminan Produk Halal pada poin 4 dan 5 disebutkan, bahwa:

1. Tata cara memperoleh Sertifikat Halal diawali dengan pengajuan permohonan Sertifikat Halal oleh Pelaku Usaha kepada BPJPH. Selanjutnya, BPJPH melakukan pemeriksaan kelengkapan dokumen. Pemeriksaan dan/atau pengujian 
kehalalan Produk dilakukan oleh LPH. LPH tersebut harus memperoleh akreditasi dari BPJH yang bekerjasama dengan MUI. Penetapan kehalalan Produk dilakukan oleh MUI melalui sidang fatwa halal MUI dalam bentuk keputusan Penetapan Halal Produk yang ditandatangani oleh MUI. BPJPH menerbitkan Sertifikat Halal berdasarkan keputusan Penetapan Halal Produk dari MUI tersebut.

2. Biaya sertifikasi halal dibebankan kepada Pelaku Usaha yang mengajukan permohonan Sertifikat Halal. Dalam rangka memperlancar pelaksanaan penyelenggaraan JPH, Undang-Undang ini memberikan peran bagi pihak lain seperti Pemerintah melalui anggaran pendapatan dan belanja negara, pemerintah daerah melalui anggaran pendapatan dan belanja daerah, perusahaan, lembaga sosial, lembaga keagamaan, asosiasi, dan komunitas untuk memfasilitasi biaya sertifikasi halal bagi pelaku usaha mikro dan kecil.

Selanjutnya, dalam Pasal 30 UndangUndang Nomor 33 Tahun 2014 tentang Jaminan Produk Halal juga disebutkan bahwa BPJPH menetapkan LPH. untuk melakukan pemeriksaan dan/atau pengujian kehalalan produk. Penetapan LPH sebagaimana dimaksud dilakukan dalam jangka waktu paling lama 5 (lima) hari kerja terhitung sejak dokumen permohonan sebagaimana dimaksud dalam Pasal 29 ayat (2) dinyatakan lengkap.

Sanksi Administratif Dan Sanksi Pidana Bagi Pelaku Usaha Yang Tidak Memenuhi Ketentuan Berproduksi Secara Halal Berdasarkan UndangUndang Nomor 8 Tahun 1999 Tentang Perlindungan Konsumen

UU Perlindungan Konsumen Nomor 8 Tahun 1999 Tentang Perlindungan Konsumen Republik

Indonesia menjelaskan bahwa hak konsumen diantaranya adalah hak atas kenyamanan, keamanan, dan keselamatan dalam mengonsumsi barang dan atau jasa; hak untuk memilih barang dan atau jasa serta mendapatkan barang dan atau jasa tersebut sesuai dengan nilai tukar dan kondisi serta jaminan yang dijanjikan; hak untuk diperlakukan atau dilayani secara benar dan jujur serta tidak diskriminatif; hak untuk mendapatkan kompensasi, ganti rugi dan atau penggantian, apabila barang dan atau jasa yang diterima tidak sesuai dengan perjanjian atau tidak sebagaimana mestinya; dan sebagainya.

Di dalam Udang-Undang Nomor 8 tahun 1999 Tentang Perlindungan Konsumen juga mengatur tentang sertifikasi halal untuk itu setiap pelaku usaha harus memproduksi barang sesuai dengan ketentuan berproduksi secara halal sesuai label halal yang telah dicantumkan.

Undang-undang Perlindungan Konsumen juga memberikan sanksi bagi pelaku usaha yang tidak mengikuti ketentuan berproduksi secara halal, sebagaimana pernyataan "halal" yang dicantumkan dalam label, berupa pidana dengan pidana penjara paling lama 5 (lima) tahun atau denda paling banyak Rp. 2.000.000.000, 00 ( dua miliar rupiah ) .

\section{KESIMPULAN DAN SARAN Kesimpulan}

Dari Perumusan Masalah yang penulis kemukakan serta pembahasannya baik yang berdasarkan teori maupun data-data ,maka penulis mengambil kesimpulan sebagai berikut

1. Sertifikasi Halal pada suatu Produk sudah diatur dalam UndangUndang Nomor 33 tahun 2014 tentang Jaminan Produk Halal yaitu diatur dalam Pasal 1 angka 10, Pasal 4, Pasal 6, di Samping itu juga diatur dalam Undang-Undang 
Nomor 8 tahun 1999 tentang Perlindungan Konsumen yang dijelaskan pada pasal 8, Peraturan Pemerintah Nomor 69 Tahun 1999 Tentang Label dan Iklan Pangan Pasal 10 ayat (1), Keputusan Menteri Agama Republik Indonesia Nomor 519 tahun 2001 tentang Lembaga Pelaksana Pemeriksaan Pangan Halal. Bentuk perlindungan hukum yang diberikan kepada konsumen terhadap pelaku Usaha yang tidak mengikuti ketentuan berproduksi secara Halal serta Produk yang belum bersertifikasi Halal telah ditentukan dengan beberapa Undang-Undang tersebut dengan memberikan Sanksi Administratif serta Pidana.

2. Dengan pencantuman label halal pada suatu Produk dianggap telah terjadi pernyataan dimaksud dan setiap orang yang membuat pernyataan tersebut bertanggung jawab atas kebenaran pernyataan tersebut. Pencantuman label halal menurut ketentuan tersebut pada akhirnya diterjemahkan sebagai suatu hal yang bersifat sukarela dan bukan lagi merupakan suatu kewajiban.Sehingga Konsumen berhak mendapatkan perlindungan Konsumen untuk Produk yang belum memenuhi ketentuan berproduksi secaraHalal dan bentuk Perlindungan hukum yang dimaksud terdapat dalam UndangUndang Nomor 8 tahun 1999 tentang perlindungan Konsumen.

\section{Saran}

1. 1.Diperlukan Peningkatkan intensitas pengawasan secara aktif dari pemerintah dengan bekerja sama dengan seluruh instansi terkait guna memberikan perlindungan konsumen. Kerjasama juga harus melibatkan Pemerintah Daerah mengingat luasnya daerah peredaran produk-produk makanan di wilayah
Indonesia. Serta meningkatkan peran serta masyarakat dalam pelaksanaan pengawasan dengan cara memberikan sebuah pembelajaran dan pelatihan, sehingga masyarakat mampu memverifikasi sendiri produk-produk makanan yang halal dengan yang tidak.

2 2. 2. Menyarankan Kepada Pemerintah untuk Merevisi peraturan perundangundangan yang mengatur tentang sertifikasi dan lebelisasi halal hingga teknisnya supaya terjadi sebuah sinkronisasi antar Peraturan Perundangundangan. Sehingga sertifikasi dan labelisasi halal menjadi suatu kewajiban yang harus dipenuhi oleh pelaku usaha guna memberikan perlindungan terhadap konsumen muslim.

\section{DAFTAR PUSTAKA}

\section{Literatur :}

4. Adam Chazawi, Kejahatan mengenai pemalsuan, PT. Raja GRaffindo Persada, Jakarta : 2005

5. Gunawan Widjaja Ahmad Yani, Hukum Tentang Perlindungan Konsumen, PT.Gramedia Pustaka Utama, Jakarta : 2008

6. Imam Masykoer Ali, Bunga Rampai Jaminan Produk Halal di Negara Anggota Mabins , Jakarta : 2003.

7. Mustafa Kamal Rokan, Hukum Persaingan Usaha (Teori dan Praktiknya di Indonesia), Jakarta : Raja Grafindo Persada, 2010.

8. Peter Mahmud Marzuki, Penelitian Hukum, Kencana Prenada Media Group, Jakarta : 2005.

9. Soerjono Soekanto dan Sri Mamuji, Penelitian Hukum Normatif, PT Raja Grafindo Persada, Jakarta : 2010.

10. Yusuf Qardawi, Halal Haram dalam Islam, Intermedia , Jakarta : 2003.

\section{Perundang-Undangan :}

1. Undang-undang Dasar Republik Indonesia 1945.

2. Undang-Undang Nomor 33 tahun 2014 Tentang Jaminan Produk Halal. 
3. Undang-Undang Nomor 8 tahun 1999 Tentang Perlindungan Konsumen.

4. Peraturan Pemerintah Nomor 69 Tahun 1999 Tentang Label dan Iklan Pangan.

5. Keputusan Menteri Agama Republik Indonesia Nomor 519 tahun 2001 tentang Lembaga Pelaksana Pemeriksaan Pangan Halal.

6. Kitab Undang-Undang Hukum Pidana ( KUHP )

\section{Internet :}

http://www.halalmui.org/muil4/index.php/ main/go_to_section/55/1360/page/1

Http://widihandoko.com/?p=868 http://www.landasanteori.com/2015/09/pe mbinaan-dan-pengawasanperlindungan.html 